\title{
ANALISIS PENGUKURAN KUALITAS PELAYANAN SISTEM INFORMASI PERBANKAN DENGAN MENGGUNAKAN COBIT 5
}

\author{
Instianti Elyana \\ Program Studi Akademi Sekretaris dan Manajemen, ASM BSI Jakarta \\ Jl. Jatiwaringin Raya No.18, Jakarta Timur \\ Instianti.iny@bsi.ac.id
}

\begin{abstract}
The role of information technology today is very necessary especially for companies that are service-based. With the development of technology and technology utilization of course can improve banking services to be better. The field of development and Information Technology is a part that will manage the Information Technology in the Company in the field of banking. Standard and banking procedures, especially in the field of service and security performance measurement of information technology using COBIT 5 Framework. So with the measurement of service quality Information System to customers can provide enter to the company and is expected to contribute suggestions and recommendations to the management proposal. that the current banking services have a good standard of Information Technology and need to improve the information system better.
\end{abstract}

Keywords : Information Technology, Cobit, service

\begin{abstract}
Abstrak
Peranan teknologi informasi saat ini sangat diperlukan terutama untuk perusahaan yang berbasis jasa pelayanan. Dengan adanya perkembangan teknologi dan pemanfaatan teknologi tentunya dapat meningkatkan pelayanan perbankan menjadi lebih baik. Bagian bidang pengembangan dan Teknologi Infomasi merupakan bagian yang akan mengelola Teknologi informasi di Perusahaan dibidang perbankan. Standart dan prosedur perbankan terutama dalam bidang pelayanan dan keamanan dilakukan pengukuran kinerja teknologi informasi menggunakan COBIT 5 Framework. Sehingga dengan adanya pengukuran kualitas pelayanan Sistem Informasi terhadap nasabah dapat memberikan masukkan untuk perusahaan serta diharapkan dapat memberikan kontribusi usulan dan rekomendansi usulan kepada pihak manajemen. bahwa pelayanan perbankan saat ini sudang memiliki standar Teknologi Informasi yang baik dan perlu untuk meningkatkan sistem informasi dengan lebih baik lagi.
\end{abstract}

Kata kunci : Teknologi Informasi, Cobit, pelayanan

\section{PENDAHULUAN}

Peranan teknologi informasi saat ini sangat diperlukan terutama untuk perusahaan yang berbasis jasa pelayanan. Dengan adanya perkembangan teknologi dan pemanfaatan teknologi tentunya dapat meningkatkan pelayanan perbankan menjadi lebih baik. Bagian bidang pengembangan dan 
Teknologi Infomasi merupakan bagian yang akan mengelola Teknologi informasi di Perusahaan dibidang perbankan. Perbankkan menggunakan fasilitas internet, internet banking, menjawab tuntutan nasabah yang menginginkan pelayanan cepat, aman, murah dan tersedia 24 jam yang dapat diakses baik melalui telephon seluler, komputer, maupun laptop.

Semakin maju Teknologi Informasi didunia Perbankan akan mempermudah transaksi dibidang perbankan. Standart dan prosedur perbankan terutama dalam bidang pelayanan dan keamanan dilakukan pengukuran kinerja teknologi informasi menggunakan COBIT 5 Framework. Pengukuran akan dilakukan dari proses penerimaan nasabah sampai dengan pengolahan transaksi. Cobit disusun oleh The IT Governance Institute ( ITGI) dan Information System Audit and Control Association (ISACA) pada tahun 1992. Edisi pertama dipublikasikan pada tahun 1996, edisi kedua pada tahun 1998, edisi ketiga tahun 2000 dan saat ini adalah edisi keempat desember 2005. COBIT berguna bagi IT Users karena memperoleh keyakinan atas kehandalan sistem aplikasi yang dipergunakan dan para manajer memperoleh manfaat dalam keputusan investasi dibidang teknologi informasi serta infrastrukturnya, menyusun strategi IT Plan, menentukan informatioan architecture[1]. Sehingga dengan adanya pengukuran kualitas pelayanan Sistem Informasi terhadap nasabah dapat memberikan masukkan untuk perusahaan serta diharapkan dapat memberikan kontribusi usulan dan rekomendansi usulan kepada pihak manajemen.

\section{METODOLOGI PENELITIAN}

\subsection{Landasan Acuan COBIT}

Mekanisme dalam pengukuran kontrol keamananan dapat menggunakan dasar acuan COBIT (Control Objectives base related Information Technology) yang menyediakan standard pengujian terhadap manajemen teknologi informasi, terdapat 4 Domain/kelompok/faktor, yakni faktor perencanaan dan pengembangan, faktor pengembangan dan implementasi , faktor dukungan dan perolehan serta faktor pemantauan dan evaluasi, COBIT menentukan status dari penerapan manajemen teknologi informasii yang dilakukan terhadap suatu sistem informasi dengan 5 (lima) alternatif tingkat kedewasaan (level of maturity) dalam menerapkan manajemen teknologi informasi suatu sistem[2].

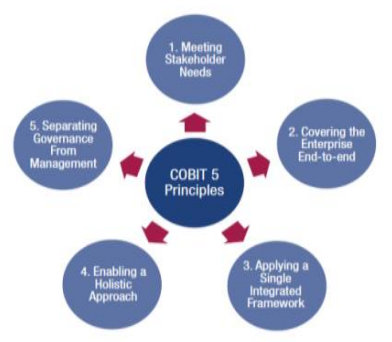

Gambar 1. Lima Dasar prinsip dalam Cobit 5 
Ada 5 (lima)alur tujuan dalam Cobit 5;

a. Prinsip 1. Memenuhi kebutuhan stakeholder

b. Prinsip 2. Melingkupi seluruh perusahaan

c. Prinsip 3. Menerapkan suatu kerangka tunggal yang terintegrasi

d. Prinsip 4. Menggunakan Sebuah pendekatan yang menyeluruh

e. Prinsip 5. Pemisahan Tata kelola dari Manajemen [3].

Kelebihan COBIT

a. Efektif dan Efisien

b. Berhubungan dengan informasi yang relevan dan berkenaan dengan proses bisnis, dan sebaik mungkin informasi dikirim tepat waktu, benar, konsisten, dan berguna.

c. Rahasia

d. Proteksi terhadap informasi yang sensitif dari akses yang tidak bertanggung jawab.

e. Integritas

f. Berhubungan dengan ketepatan dan kelengkapan dari sebuah informasi.

g. Ketersediaan

h. Berhubungan dengan tersedianya informasi ketika dibutuhkan oleh proses bisnis sekarang dan masa depan.

i. Kepatuhan Nyata

j. Berhubungan dengan penyediaan informasi yang sesuai untuk manajemen [4].

\subsection{Kerangka penelitian}

Kerangka penelitian ini terdiri dari beberapa tahap, yaitu:

1. Pengamatan awal, melalui pengamatan langsung terhadap prosedur yang berjalan dalam sistem perbankkan yang ada di masyarakat sebagai nasabah. Pengamatan awal meliputi : pengamatan langsung atau wawancara terhadap pengguna sistem informasi.

2. Penyusunan kerangka pertanyaan kinerja teknologi infomasi berdasarkan Cobit. Terdapat 4 domain utama pertanyaan, yaitu 1 . Perencanaan dan Organisasi, pengadaan, 2. Pengadaan dan implementasi, 3. Pengiriman dan dukungan, 4. Pengawasan dan evaluasi.

3. Pengisian instrument COBIT oleh sample 30 nasabah yang berbeda perusahaan. Responden mengisi kuesioner yang dirancang dengan pembobotan menggunakan skala Likert, yaitu sangat setuju ( 5), Setuju (4), cukup Setuju (3), Tidak setuju (2) dan sangat tidak setuju (1).

4. Analisa kinerja teknologi informasi dilakukan berdasarkan kuesioner yang telah diisi oleh 30 nasabah yang berbeda. Kuesioner diolah dengan mencari nilai rata-rata dan tingkat Matury tiap kode pada Cobit dan selanjutnya dilakukan pencarian rata-rata pada tiap-tiap domain Cobit.

\subsection{Langkah-langkah Penelitian}

Langkah-langkah dalam penelitian ini dilakukan dengan beberapa tahap, yaitu : 
1. Untuk keperluan data pengambilan sampel disesuaikan dengan topik yang akan diambil yaitu nasabah beberapa bank yang menggunakan Teknologi Sistem Informasi.

2. Penyusunan kuesioner data sumber referensi yang dikumpulkan.

3. Analisa jawaban responden yang kemudian dianalisa berdasarkan kerangka variabel yang ditetapkan untuk menemukan keabsahan analisis yang dikerjakan

Kesimpulan dari hasil berupa poin hipotesis. Rangkaian hipotesis sesuai dengan kondisi yang ada dilapangan

\section{HASIL PEMBAHASAN}

\subsection{Analisis Pengujian pelayanan transaksi}

Dengan menggunakan metode deskriptif kuantitatif, yang menilai dan melakukan pengamatan langsung terhadap objek penilaian dengan rentang skala pengujian $0-1,5=$ buruk, $1,6-2,5=$ tidak jelas, $2,6-3,5=$ perlu pengembangan, 3,6 $-4=$ puas, maka nilai yang diperoleh adalah 2,7 pada tingkat pengembangan.

Tabel 1. Capability Maturity Model ( CMM)

\begin{tabular}{|c|c|c|l|}
\hline No & $\begin{array}{c}\text { Nilai } \\
\text { Rata- } \\
\text { rata }\end{array}$ & Tingkat & \multicolumn{1}{|c|}{ Kriteria } \\
\hline 1 & $\begin{array}{c}0.5 \mathrm{~s} / \mathrm{d} \\
1.5\end{array}$ & Initial & $\begin{array}{l}\text { Proses dilakukan berdasarkan inisiatif nasabah } \\
\text { perorangan tanda adanya suatu standar }\end{array}$ \\
\hline 2 & $\begin{array}{c}1.5 \mathrm{~s} / \mathrm{d} \\
2.5\end{array}$ & Repeatable & $\begin{array}{l}\text { Proses dilakukan secara rutin tetapi tidak ada } \\
\text { aturan dan pandual formal }\end{array}$ \\
\hline 3 & $\begin{array}{c}2.5 \mathrm{~s} / \mathrm{d} \\
3.5\end{array}$ & Defined & $\begin{array}{l}\text { Proses dilakukan secara rutin sesuai standar } \\
\text { formal tertulis }\end{array}$ \\
\hline 4 & $\begin{array}{c}3.5 \mathrm{~s} / \mathrm{d} \\
4.5\end{array}$ & Manage & $\begin{array}{l}\text { Proses dilakukan secara rutin sesuai dengan } \\
\text { suatu standar dan terukur hasilnya }\end{array}$ \\
\hline 5 & $\begin{array}{c}4.5 \mathrm{~s} / \mathrm{d} \\
5.5\end{array}$ & Optimized & $\begin{array}{l}\text { Proses dilakukan secara rutin sesuai dengan } \\
\text { suatu standar, terukur hasilnya dan senantiasa } \\
\text { disempurnakan }\end{array}$ \\
\hline
\end{tabular}

Tabel 2. Hasil pengukuran pelayanan keamanan berdasarkan COBIT

\begin{tabular}{|c|c|c|c|}
\hline No & Domain & Tingkat kemapanan & Keterangan \\
\hline 1 & Perencanaan dan pengembangan & 4 & Manage \\
\hline 2 & Pengembangan dan implementasi & 4 & Manage \\
\hline 3 & Dukungan dan perolehan & 4,5 & Manage \\
\hline 4 & Pemantauan dan evaluasi & 4.5 & Manage \\
\hline
\end{tabular}

Dari Tabel diatas pengukuran tingkat pelayanan hasil pengujian terhadap Teknologi informasi pelayanan perbankan yang mengacu pada COBIT, hasilnya 4,5 artinya teknologi informasi yang digunakan dan dibangun memiliki status Manage namun masih banyak parameter kontrol yang harus diperbaiki dan ditingkatkan agar mendapatkan hasil yang optimal. 
Tabel 3. Hasil Audit : Pengantaran dan Dukungan (Delivery dan Support)

\begin{tabular}{|l|l|l|c|c|}
\hline No & Kode & \multicolumn{1}{|c|}{ Proses dan mengatur } & $\begin{array}{c}\text { Hasil } \\
\text { Pengujian }\end{array}$ & $\begin{array}{c}\text { Tingkat } \\
\text { Maturity }\end{array}$ \\
\hline 1 & DS1 & $\begin{array}{l}\text { Menetapkan dan } \\
\text { tingkat layanan }\end{array}$ & Manage \\
\hline 2 & DS2 & $\begin{array}{l}\text { Pengaturan layanan dengan } \\
\text { pihak ketiga }\end{array}$ & 3,1 & Defined \\
\hline 3 & DS3 & Mengatur kinerja dan kapasitas & 3,7 & Manage \\
\hline 4 & DS4 & $\begin{array}{l}\text { Memastikan ketersediaan } \\
\text { layanan }\end{array}$ & 3,9 & Manage \\
\hline 5 & DS5 & Memastikan keamanan sistem & 4,4 & Manage \\
\hline 6 & DS6 & $\begin{array}{l}\text { Indentifikasi dan biaya } \\
\text { tambahan }\end{array}$ & 3,7 & Manage \\
\hline 7 & DS7 & Mendidik dan melatih user & 3,9 & Manage \\
\hline 8 & DS8 & $\begin{array}{l}\text { Mengelola bantuan layanan dan } \\
\text { insiden }\end{array}$ & 3,9 & Manage \\
\hline 9 & DS9 & Mengatur konfigurasi & 3,7 & Manage \\
\hline 10 & DS10 & Mengelola masalah & 3,5 & Manage \\
\hline 11 & DS11 & Mengelola data & 3,4 & Manage \\
\hline 12 & DS12 & Mengelola fasilitas & 3,7 & Manage \\
\hline 13 & DS13 & Mengelola Operasi & Manage \\
\hline
\end{tabular}

Tabel 3. Hasil dari audit rata-rata proses dari domain pengantaran dan dukungan teknologi informasi dilapangan dengan responden pengguna pelayanan perbankan memberikan hasil yang baik dengan tingkat Matury : Manage $(3,7)$ atau proses pengantaran dan dukungan terhadap teknologi informasi sudah dilaksanakan secara rutin sesuai standar dan hasilnya telah diukur. Proses keamanan Sistem (DS5) tingkat maturity-nya Manage $(4,4)$ atau proses kepastian keamanan sistem (DS5) tingkat maturity-nya manage $(4,4)$ atau proses selain dilaksanakan secara rutin sesuai standar.

Tabel 4. Hasil Audit TI : Pengadaan dan implementasi

\begin{tabular}{|l|l|l|c|l|}
\hline No & Kode & Proses & $\begin{array}{l}\text { Hasil } \\
\text { Pengujian }\end{array}$ & $\begin{array}{l}\text { Tingkat } \\
\text { Maturity }\end{array}$ \\
\hline 1 & AI1 & Identifikasi solusi-solusi otomatis & 3.6 & Manage \\
\hline 2 & AI2 & $\begin{array}{l}\text { Mendapatkan dan memelihara } \\
\text { perangkat lunak aplikasi }\end{array}$ & 3.8 & Manage \\
\hline 3 & AI3 & $\begin{array}{l}\text { Mendapatkan dan memelihara } \\
\text { infrastruktur teknologi }\end{array}$ & 3.0 & Defined \\
\hline 4 & AI4 & $\begin{array}{l}\text { Menjalankan operasi dan } \\
\text { menggunakannya }\end{array}$ & 3.0 & Defined \\
\hline 5 & AI5 & $\begin{array}{l}\text { Pengadaan sumber daya teknologi } \\
\text { informasi }\end{array}$ & 3.0 & Defined \\
\hline 6 & AI6 & Mengelola perubahan & 3.2 & Defined \\
\hline
\end{tabular}


Pada tabel 4 proses mendapatkan dan memelihara infrastruktur teknologi ( AI3), menjalankan operasi dan menggunakanya ( AI4), pengadaan sumber daya teknologi (AI5) memiliki tingkat maturity : defined ( 3.0) dan hasil auditnya cukup baik dengan rata-rata tingkat maturity : defined (3.0) yang berarti pada dasarnya proses tersebut telah telah dilakukan sesuai dengan standar.

\section{SIMPULAN}

Berdasarkan indeks maturity total untuk Domain keseluruhan hasil pengukuran menempatkan pelayanan perbankan berbasis teknologi informsi dalam posisi matury antara level 3 (Defined Level) dan level 4 (Managed Level) yang menggambarkan tingkat maturity sebuah perusahaan perbankan terdefini dengan baik dokumentasi yang lengkap dan terintegrasi digambarkan pada level 3 sedangkan pada level matury pelayanan terolah dengan baik dari segi pengukuran hasil, kontrol proses dan pengaturan sistem. Maka ditarik kesimpulan bahwa pelayanan perbankan saat ini sudang memiliki standar Teknologi Informasi yang baik dan perlu untuk meningkatkan sistem informasi dengan lebih baik lagi.

\section{DAFTAR PUSTAKA}

[1] Gondodiyoto, S., 2007, "Audit Sistem Informasi + Pendekatan COBIT", Penerbit MitraWacana Media.

[2] IT Governance Institute, "COBIT Framework 4.1 Edition, 2007" http://www.isaca

[3] Nanang Sasongko dan Frita Lussi B (2013), Pengukuran kinerja Audit Sistem Informasi, Pada Bank BPR Jawa Barat, Prosiding, Forum Manajemen Indonesia ke 5 , Universitas Tanjung.

[4] Diana Trivena Yulianti dan Michel Canggih Patria, 2011. "Audit Sistem Informasi Sumber Daya Manusia Pada PT X Menggunakan Cobit Framework 4.1". Jurnal Ilmiah, Universitas Kristen Maranatha, Bandung. 